iotic patients, that might suggest an increased plasma somatonedin activity. In a limited study, a significant difference was cound between the plasma somatomedin activity of children with zongenital scoliosis and normal children.

\section{RIEFERENCISS AND NOTES}

1. Daughaday, W. H., Hall, K., Raben, M. S.. Salmon. W. D.. Van den Brande J. L., and Van Wyk, J. J.: A proposed designation for the sulphation factor.' Nature. 23.5: 107 (1972)

2. Du Caju. M. V. L., and Van den Brande, J. L..: Plasma somatomedin levels in growth disturbances. Acta Patediat. Scand., 62: 96 (1973).

3. Finney, D. J.: Statistical Methods in Biological Assay (Griffin, Londen. 1952).

4. Hall, K., and Uthne, K.: Some biological properties of purified sulphation factor from humin plasma. Acta Med. Scand., 190: 137 (1971)

5. Kazmin, A. I., and Merhureva, R. V.: Aminopolyglycan stalo-, and glyooprotein content in the spine tissue of pattents with scoliosis (in Russian) Ortop. Travmatol. Protez. (NGoskva), 30: 20 (1969)

6. Kaz'min. A. I. and Merkur'eva, R. V.: Role of glycosaminglycan metabolism disorders in the pathogencis of scoliosis (in Russian). Ortop. Travmatol. Protez (Moskva). 32: 87 (1971).

7. Misol. S., Ponseti, I. V., Samaan, N., and Bradbury, J. T.: Growth hormone bood leveis in pattents with idiopathic scoliosis. Clin. Orthop., 821 : $122(1972)$

Copyright (1) 1977 International Pediatric Reseatch Foundation, Ine.
8. Ponseti, I V. The pathogenesis of adolescent scoliosis. In (P. A. Zorab: Proceedings of a Second Symposium on Scoliosis: Causation, p. 60) (Livingstone. London, 1968)

9. Ponseti, 1. V. Pedrini-Mille, A., and Pedrini, V.: Histological and chemical analysis of human iliac crest cartilage. Calcif. Tissue Res..2: $197(1968)$.

10. Roaf. R.: The basic anatomy of scoliosis. J. Bone Joint Surg., 48B: 786 $(1966)$

11. Salmon, W. D., and Dalughaday, W. H.: A hormonally controlled serum factor which stimulates sulphate incorporation by cartilage in vitro. J. Lab. (lin. Med. 49: 825 (1957)

12. Van den Brande, J. L. and Du Caju, M1. V. L.: An improved technique for measuring somatomedin activity in vitro. Acta Endocrinol. $75: 233$ (1974).

13. Willoer, S.: A study of height, weight and menarche in girls with idiopathic scoliosis. Acta Orthop. Scand. 46: 71 (1975).

14. Zorab. P. A., Clark. S., Cotrel, Y., and Harrison, A.: Bone collagen turnover in idiopathic scoliosis estimated from total hydroxyproline excretion. Arch. Dis. Childhood, 46: 828 (1971).

15. We are grateful to Mr. C. W. Manning. Mr. P. F. Milling, and M. Yves Cotrel for their help in the collection of hlood samples, and to D). J. L. Van den Brande for encouragement and technical advice.

16. This research was supported by the Wellconk Foundation. The Brompton Hospital Research Fund, and St. Mary's Hospital, Paddington UK.

17. Requests for reprints should be addressed to: G. S. (j. Spencer, (irowth Section. Meat Research Institute. Langford, Bristol (UK).

18. Received for publication November 3, 1976

19. Accepted for publication January 27, 1977.
Blood volume growth hormone idiopathic short stature red cell mass

Russell-Silver dwarfism

\title{
The Effect of Growth Hormone Deficiency and of Growth Hormone Substitution on Blood Volume and Red Cell Parameters
}

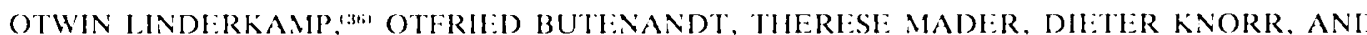 \\ KLAUS P. RII:GEI.
}

Deparment of Pediatrics, University of Munich, Munich, Federal Republic of Germany

\begin{abstract}
Summary
Blood volume, plasma volume and red cell mass, red cell parameters, reticulocytes, serum iron, and total iron binding capacity were investigated. Fifty-nine growth-retarded children were studied: 27 children with idiopathic short stature (ISS) and 32 children with isolated growth hormone deficiency (GIID)). Fifteen of the GHI) patients were studied before treatment and again 3-6 months after onset of treatment with growth hormone, 3 GIII) patients only before and 14 only during treatment. Blood volume, plasma volume, and red cell mass were significantly $(P<0.005)$ decreased by $15 \%$ in the untreated (GII) patients and were normal in the children studied during treatment with growth hormone compared with the values in ISS patients. In the 15 GHID patients studied before and during treatment, blood volume, plasma volume, and red cell mass increased by $17 \%$ to normal values $(P<0.0005)$ on treatment with growth hormone. No significant differences were demonstrable between values related to actual body weight and to corrected weight for height. Hematocrit, mean corpuscular volume, and reticulocytes remained unchanged. Serum iron and
\end{abstract}

total iron binding capacity were normal before treatment. Serum iron increased and total iron binding capacity decreased significantly during growth hormone substitution. In a pair of twins with Russell-Silver dwarfism and GHD, growth hormone increased blood volume, plasma volume, and red cell mass as in the other GHD patients. In another pair of twins with RussellSilver dwarfism without GHI), growth the hormone was without effect on blood volume.

\section{Speculation}

Our results of decreased blood volume and red cell mass in children with isolated GIID) and the increase of blood volume and red cell mass during growth hormone treatment provide direct evidence that growth hormone is stimulating erythropoiesis. The less pronounced decrease of blood volume and red cell mass in our patients compared with the literature data obtained on panhypopituitary and hypophysectomized subjects may indicate that growth hormone, thyroxin, and other hormones act synergistically on erythropoiesis. 
In children with panhypopituitarism or isolated GHD, blood volume, plasma volume, and red cell mass were found to be decreased by approximately $30 \%$ below normal $(28,30)$. Therefore, Shahidi and coworkers (30) recommended checking of blood volume in order to distinguish between dwarfism due to panhypopituitarism or GIID and idiopathic short stature. Their reports, however, include only one patient with isolated GIID (28), or do not differentiate between children with isolated GIID and panhypopituitarism (30). The effect of growth hormone on blood volume in isolated GIID has not yet been studied.

\section{MATERIALS AND MI:THODS}

Fifteen patients with GlID, including one pair of twins with Russell-Silver dwarfism, were studied before treatment and again 3-6 months after onset of treatment with human growih hormone (10 IU/m²/weck). In addition, 3 GHID patients before treatment, and $1+$ during treatment were examined. The control group comprised 27 children with idiopathic short stature. Furthermore, another pair of twins with Russell-Silver dwarfism but without GHD was studied before and during treatment with growth hormone. No further treatment was performed. Informed consent was obtained from patients and/or parents in every case before investigation was started. Since children with hypopituitarism are often overweight for height (17). we obtained the "appropriate" (corrected) weight for the actual height from nomograms (21). The age distribution was similar in all groups (5-18 vears). The endocrine studies performed in all children included determination of growth hormone (insulin tolerance test), thyroxin, cortisol, and gonadotropins by standard procedures (radioimmunoassays). The children with ISS were without endocrine abnormalities and the patients with GHID were without further endocrine abnormalities. A possible gonadotrophic deficiency camnot be rukd out in prepubertal children.

Hematocrit was measured by the microhematecrit method using a correction factor of 0.98 for trapped plasma (23). Reticulocytes were counted after staining with brilliant cresyl blue. Serum iron and total iron-binding capacity (TIBC) were determined by the use of sulfonated bathophenanthroline. Plasma volume was measured by means of Fvans blese dye injected in doses of $0.2 \mathrm{mg} / \mathrm{kg}$. Details of the method emplosed are described elsewhere (22). The postmix blood sample was taken 10 min after injection of the dee. In 10 patients the disappearance rate of Evans blue was estimated by taking four to six blood samples within $1 \mathrm{hr}$ after injection of the dye. These studies revealed a mean error of $+1.0 \pm 2.6 \%$ (SD) by dye disappearance if only one blood sample was taken 10 min after the injection of the dee. Blood volume and red cell mass were calculated from plasma volume and hematocrit using a body/ venous hematocrit ratio of $0.91(7.10)$. This method catuses significant error if the body/venous hematocrit ratio is markedly different from 0.91. Blood volume determination by double isotope techniques in children suffering from hypopituitarism (28) showed a mean body/senous hematocrit ratio of $0.90 \pm$ $0.07(\mathrm{SD})$ if the reported hematocrits were corrected for trapped plasma. Therefore, our method seems to be adequate and has the advantage of preventing the hazards of radiation exposure

\section{RISSULTS}

The individual data of blood rolume and red cell mass per $\mathrm{kg}$ body weight are shown in Figure 1. In reference to corrected weight for height the values of the GHD patients were slightly higher. Nevertheless, blood volume, plasma volume, and red cell mass related to both actual body weight and corrected weight for height were significantly lower $(P)<0.005)$ in the untreated children with GHID in comparison to the children with idiopathic short stature (Table 1).

In any of the patients studied twice, blood volume, plasma

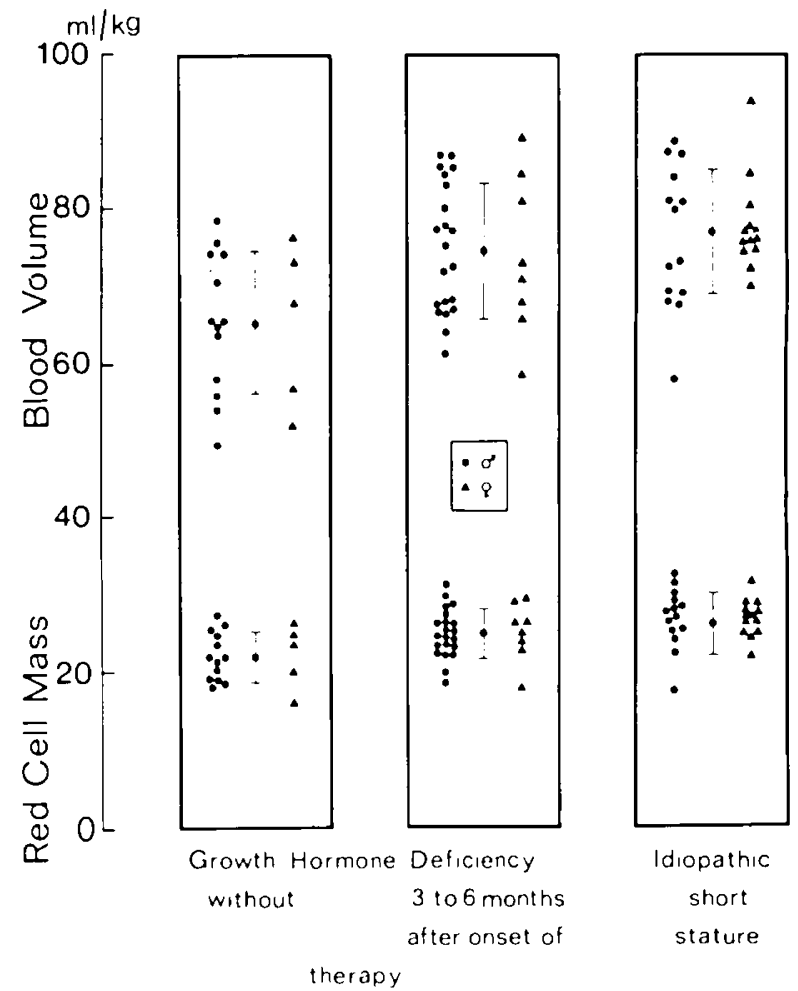

Fig. 1. Blood volume and red cell mass in children with short stature. Values related to actual body weight.

volume, and red cell mass increased during treatment with growth hormone (Fig. 2). Furthermore, serum iron decreased and TIBC increased significantly during treatment, whereas hematocrit, mean corpuscular volume ( $M C \mathrm{CV}$ ), and reticulocytes remained unchanged (Table 2). Two pairs of twins with RussellSilver dwarfism were studied before. and 3-6 months after the initiation of growth hormone therapy (Fig. 3). One of the pairs wats without endocrine abnormalities; the other pair had Glid). Bleod volume, plasmat volume. and red cell mass increased only in the twins with (illD) during treatment.

\section{DIS( USSION}

The present study provides evidence that the fotal blood volume is reduced by approximately $15 \%$ below normal values in children with isolated (illi) because of an eyual reduction of plasma volume as well as of red cell mass. The effect of pituitary deficiency on plasma volume and red cell mass has been studied extensively by several authors in hypophysectomized animals. In hypophysectomized rats. red cell mass is decreased by about fore. whereas plasma volume is normal or only slightly decreased, resulting in a marked peripheral anemia (1.2. 5. 11. 12.16.24.29). In dogs and monkeys. hypophysectomy does not change hematocrit but reduces plasma volume and red cell mass: in monkeys by $30 \%$ (28, 32) and in dogs by $46 \%$ (4). Few similar studies on blood volume have been done in the pituitarydeficient human. Hypophysectomy in adult patients results in a parallel decrease of plasma volume and red cell mass by about $40 \%(14)$ and in children with panhypopituitarism by $30 \%$ (28).

In a recent study of a group of 10 children suffering from panhypopituitarism or isolated (GHD a reduction of plasma volume and red cell mass by about 30 \% was shown (30). The blood volume values in any of these patients were below the range of children with short stature without endocrine abnormalities. The authors concluded that the determination of red cell mass and plasma volume may be of discriminating value in children with short stature. However, in contrast to this mixed group, our patients with isolated GHI) showed less pronounced volume 
Table 1 . Hematologic values (means $\pm S D)$ of untreated and growth hormone-treated children with growth hormone deficiency (CHD) and of children with idiopathic short stature (ISSS)'

\section{Human GIII)}

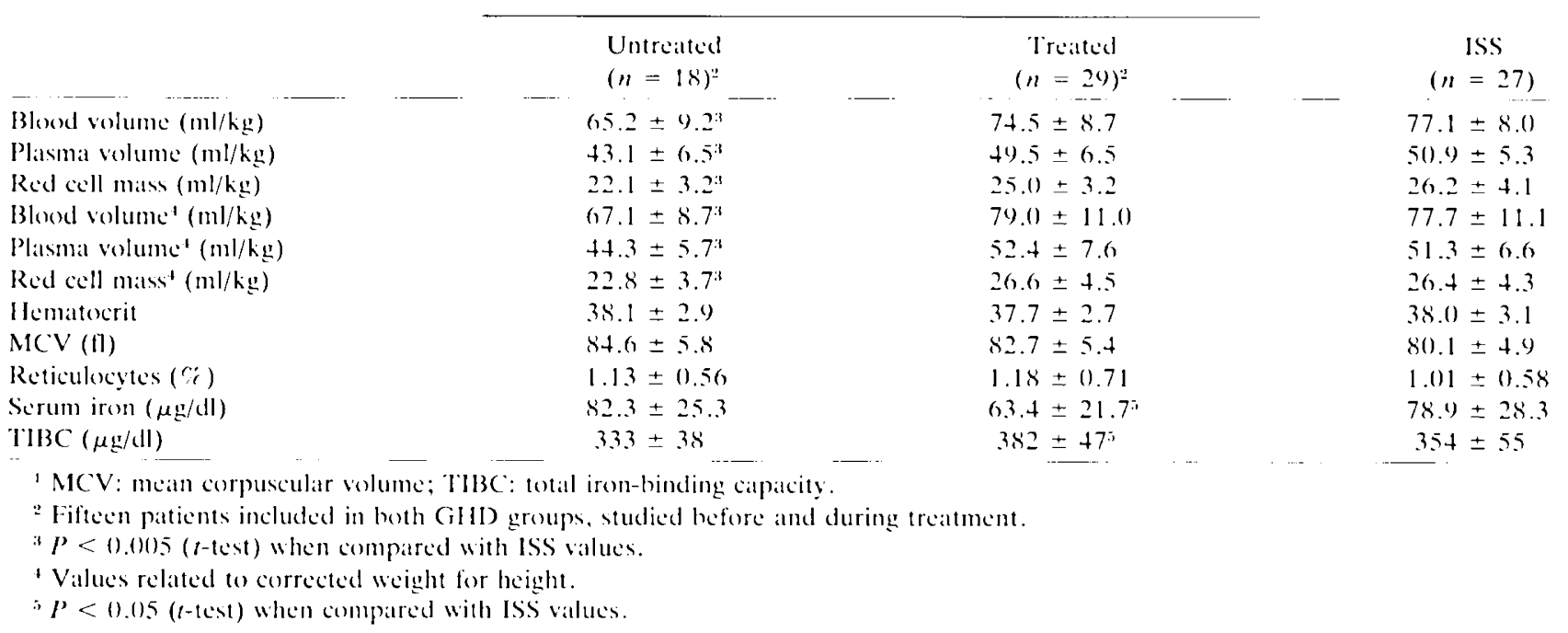

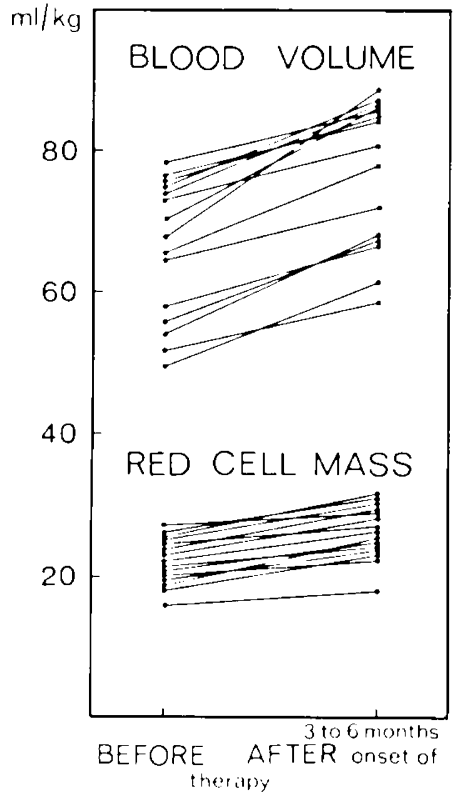

Fig. 2. Effect of treatment with human growth hormone on blood volume and red cell mass in 15 children with growth hormone deficiency.

reduction. and the individual values scattered over the lower half of the normal range (Fig. I).

The comparison of blood volume data simply on the basis of body weight might be misleading. since children with hypopituitarism are often owerweight for height (17). Lean body mass as reference standard for blood volume has been found to be most accurate, especially in obese subjects (13). A rough estimate of lean body mass can be obtained by using normal ("corrected") weight for height as a reference standard (1.3). In our patients with GHD blood volume, plasma volume, and red cell mass related to corrected weight for height were slightly, but not significantly, higher in comparison with the values referred of actual body weight. ()ur results of a less marticd reduction in blood volume compared with the data obtained from hypophysectomized adult patients and children with panhypopituitarism may be explained by the normal thyroxin and cortisol metabolism in our patients.

In hypoplysectomized animals the combined administration of thyroxin and growth hormone restores red cell mass and blood
Table 2. Effect of treatment with human growth hormone for 3-6 months on he'matologic values in 1.5 childre'n with growth hormone deficiency.1

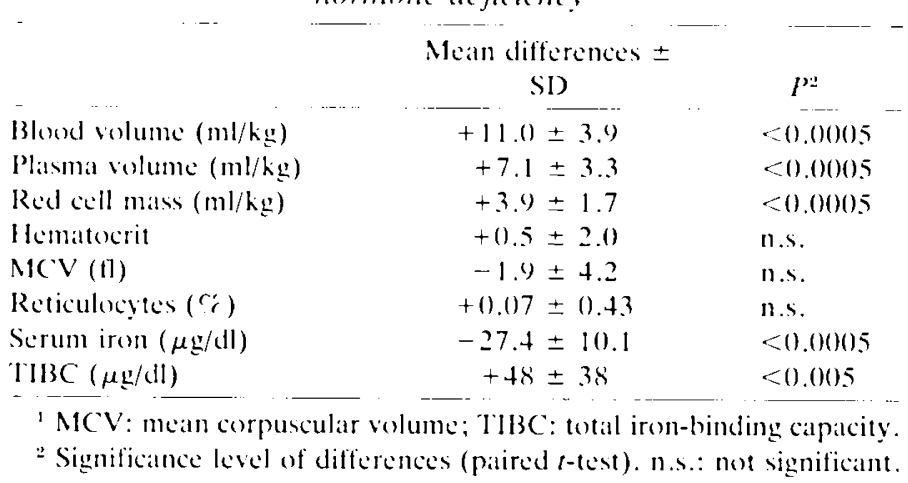

volume to normal values (11,32). In the human the combined treatment with thyroxin, adrenal steroids, growth hormone, and testosterone normalizes red eell mass and increases plasma volume by loce above normal in panhypopituitarism (20). The influence of growth hormone on blood volume has not yet been studied in children with isolated GHD. Our results show that in children with GIID administration of growth hormone normalizes total blood volume, plasma volume, and red cell mass. In the two patients with Russell-Silver dwarfism without GliD, growth hormone did not influence hematologic values. In analogy to these results growth hormone fails to increase red cell mass in intact rabbits and polycy themic mice (18).

Reduction in red cell mass can be the result of shortened red cell life span or decreased erythropoiesis. Hematologic studies in hypophysectomized animals revealed normal red cell survival time (4). reduction in the erythroid elements in bone marrow $(11,32)$, decreased erythropoictin activity $(6,32)$, decreased erythropoietic response to hypoxia $(3.19)$. decreased plasma iron turnover and iron uptake by red cells $(3,4,6)$, and normal erythrocyte 2,3-diphosphoglycerate (28). These data and our results of normal reticulocyte counts, serum iron, and THBC indicate that the reduction in red cell mass in panhypopituitarism and isolated GHD is solely due to decreased erythropoicsis.

On the other hand, in pituitary-deficient subjects, growth hormonc increases erythropoictin activity $(20,26,30,32)$, iron incorporation into newly formed red cells (25), 2.3-diphosphoglyecrate, and red cell enzyme activities that are present at a higher level in younger red cells $(9,28,30,31,32)$. These 


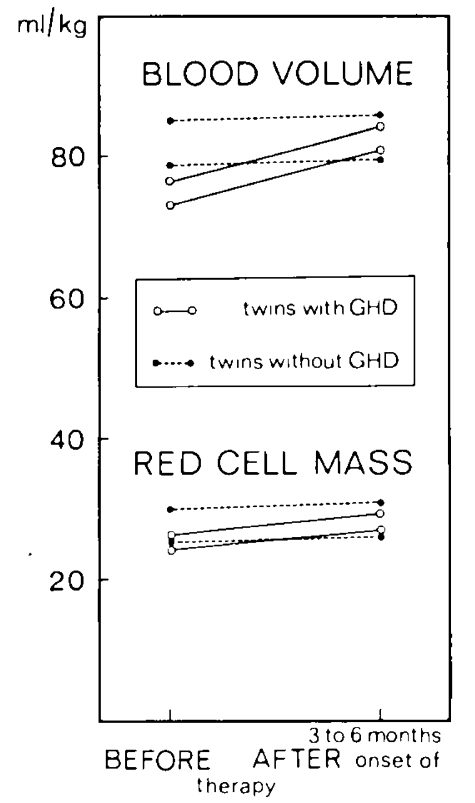

Fig. 3. Effect of treatment with human growth hormone on blood volume and red cell mass in two pairs of twins with Russell-Silver dwarfism. GHD: growth hormone deficiency.

observations, together with our results of an increase in red cells mass in children with isolated GHD, indicate that growth hormone stimulates erythropoiesis. Likewise, our finding of moderate iron deficiency in the growth hormone-substituted patients can be explained by stimulated erythropoiesis. Reticulocyte counts are found to be increased only during the first 10 weeks of growth hormone substitution (9), and therefore were normal in our patients studied 3-6 months after onset of treatment.

How growth hormone acts on erythropoiesis is still open to question. The widely held opinion that growth hormone influences erythropoiesis by increasing oxygen consumption $(11,14$. $20,28,30)$ seems to be doubtful, at least in children, since basal metabolic rate does rise in some children with hypopituitarism, but not in all after growth hormone substitution $(8,27)$. A direct action of growth hormone on erythropoictin activity and/or on bone marrow seems to be more likely $(15,25)$.

\section{CONCLUSION}

Blood volume studies (Evans blue method) in children with isolated GHD showed the mean blood volume (BV), plasma volume (PV), and red cell mass (RCM1) to be significantly lower than in children with idiopathic short stature. BV. PV, and RCM in 29 GHD patients treated with growth hormone for 3-6 months were normal. Fifteen children were studied before as well as during treatment. BV, PV, and RCM increased in all of these patients. Iron level in serum was decreased during growth hormone substitution. most probably because of increased erythropoicsis.

\section{REFERENCES AND NOTES}

1. Berlin, N. I., van Dyke, D. C., Siri, W. E., and Williams, C. P.: The effect of hypophysectomy on the total circulating red cell volume of the rat. Endocrinology, 47: 429 (1950).

2. Bond, C. F., and Leonard, S. L.: Factors affecting blood volumes in hypophysectomized female rats. Amer. J. Physiol., 191: 296 (1957).

3. Bozzini. C. E., Barrio Rendo, M. E., and Tomio. J. M.: Decreased erythropoietic response of hypophysectomized rats to lowered barometric pressures. Acta Physiol. Latincam., 18: 114 (1968).

4. Bozzini. C. E., Houssay, A. B., Varela, J., Barrio Rendo, M. E., Alvarez Ugarte, C. A., and Wagner, A.: The effect of hypophysectomy on erythropoiesis in the dog. Acta Physiol. Latinoam., 14: 12 (1964)

5. Bozzini, C. E., Kofoed, J. A., Niotti, H. F., Alippi, R. M., and Barrioneuvo,
J. A.: Relationship of red cell mass and energy metabolism to lean body mass in hypophysectomized rats. J. Appl. Physiol., 29: 10 (1970).

6. Bozzini, C. E.. Kremenchuzky, S., Houssay. A. B., Varela, J. E., and Barrio Rendo, M. F.: Erythropoiesis-stimulating activity in the plasma of normal, thyroidectomized and hypophysectomized dogs. Acta Physiol. Latinoam., 14: $146(1964)$.

7. Bratteby, L. E.: Studies on erythro-kinetics in infancy. VIII. Mixing, disappearance rates and distribution volume of labelled erythrocytes and plasma proteins in early infancy. Acta Soc. Med. Upsal., 72: 249 (1967).

8. Bryson, M. F., Forbes, G. B., Amirhakimi, G. H., and Reina, J. C.: Metabolic response to growth hormone administration, with particular reference to the occurrence of hypercalciuria. Pediat. Res.. 6: 743 (1972).

9. Butenandt, O.: Anderungen von Erythrozytenenzymen unter der Therapie mit humanem Wachstumshormon. Nova Acta Leopold. 40: 261 (1974).

10. Chaplin, H., Mollison, P. L., and Vetter, M.: The body/venous hematocrit ratio, its constancy over a wide hematocrit range. J. Clin. Invest., 32: $1309(1953)$.

11. Crafts, R. C., and Meineke, H. A.: The anemia of hypophysectomized animals. Ann. N. Y. Acad. Sci., 77: 501 (1959).

12. Dyke, D. C. van, Contopoulos, A. N., Williams, B. S., Simpson, M. E., Lawrence, J. H., and Evans, H. M.: Hormonal factors influencing erythropoiesis. Acta Haematol., 11: 203 (1954).

13. Edwards, K. D. G., and Whyte, H. M1.: The relation of blood volume to body composition. Clin. Sci., 19: 399 (1960).

14. Falkheden, T., Sjögren, B., and Westling. H.: Studies on the blood volume following hypophysectomy in man. Acta Endocrinol., 42: 552 (1963).

15. Fisher, J. W., Roh, B. L., Couch, C., and Nightingale, W. O.: Influence of cobaldt, sheep erythropoietin and several hormones on erythropoiesis in bone marrow of isolated perfused hind limbs of dogs. Blood. 23: 87 (1964).

16. Gemzell. C. A., and Sjöstrand, T.: Effect of hypophysectomy, ACTH and growth hormone on total amount of hacmoglobin and blood volume in male rats. Acta Endocrinol., 16: 6 (1954).

17. Grunt, J. A., and Enriquez, A. R.: Acute and Jeng-term responsiveness to growth hormone in children with short stature. Pediat. Res., 6: 664 (1972).

18. Halvorsen, S.: Effects of growth hormone on erythropoiesis in the intact rabbit ard the polycythemic mouse. Acta Physiol. Scand.. 66: 203 (1966).

19. Halvorsen, S., White, R. P., Roh, B. L... and Fisher, J. W.: Hypothatamic influences on erythropoiesis: Effects of hypothalamic stimulation on plasma erythropoictic activity and renal blood flow in intact and hypophysector mized rabbits. In: Regulation of Erythropoiesis: First International Conference on Hematopoiesis, October 1971, Capri, Italy, p. 247.

20. Jepson, J. H., and McGarry, E. E.: Hemopoiesis in pituitary dwarfs treated with human growth hormone and testosterone. Blood, 39: 238 (1972).

21. Kunze, D.. and Murken, J. D.: Diagnostik von Längenalter und Gewichtsalter mit neuen Somatogrammen. Kinderarzt, 5: 1077 (1974).

22. Linderkamp, O., Mader, T., Butenandt, O., and Riegel, K. P.: Plasma volume estimation in severely ill infants and children using a simplified Evans blue method. Europ. J. Pediat., 125: 135 (1977).

23. Linderkamp, O., Roth, G.. Sengespeik, C., Versmold, H., and Ricgel, K.: Blutvolumen. Serumeisen und Erythrozytenparameter von ausgetragenen, früh abgenabelten Säuglingen im ersten Lebensjahr. Ḱlin. Pädiat., 186: 511 (1974)

24. Meincke, H. A., and Crafts, R. C.: Correlation between oxygen consumption and erythropoiesis in hypophysectomized rats treated with various doses of thyroxin. Proc. Soc. Exp. Biol. Med.. 102: 121 (1959).

25. Meineke, H. A., and Crafts, R. C.: Further observations on the mechanism by which androgens and growth hormone influence erythropoiesis. Ann. N. Y. Aciad. Sci.. 149: 298 (1968)

26. Peschle, C., Rappaport, I. A., Sasso, G. F., Gordon, A. S., and Condorelli, M.: Nechanism of growth hormone (GH) action on erythropoicsis. Fendor crinology. 91: 511 (1972).

27. Prader, A., Zachmann, M.. Poley, J. R., and Illig, R.: The metabolic effect of a small uniform dose of human growth hormone in hypopituitary dwarfs and in control children. Acta Endocrinol. 57: 115 (1968).

28. Rodriguez, J. M... and Shathidi, N. T.: Erythrocyte 2.3-diphosphoglycerate in adaptive red-cell-volume deficiency. N. Engl. J. Med.. 285: 479 (1971).

29. Rosenkranz, A., Bozzini, C. E.. Alvarez Ugarte, C. A., Martinez, M. A.., and Mazzaferri. E.: Red cell volume and composition of the carcass of hypophysectomized male rats after injections of testosterone. J. Endocrinol., 63 : $259(1974)$

30. Shahidi, N. T., Vitale, L. F. Desai, J. N., Rao, L. M., Kerr, G. R. and Tuffli, G. A.: Blood volume and erythrocyte 2,3-diphospheglycerate in growth hormone deficiency. In: Advances in Juman Growth Hormone Research. p. 920. Symposion. October 1973. Baltimore (United States Department of Health, Education and W'elfare, NIII Publication no. 7.t$612,1973)$.

31. Stahnke, N., Blunck, W.., and Schröter, W.: Action of growth hormone on erythropoiesis: Changes in red blood cell enzyme activities in growthretarded patients with and without growth hormone deficiency. Pediat. Res., 10: 802 (1976).

32. Vitale. L.. Shahidi, N. T., Kerr. G. E., Wolf, R. C., Korst, D. R., and Meser, R. K.: The role of grow th hormone and thyroxine in erythropoietic restoration in hypophysectomized monkeys. Proc. Soc. Exp. Biol. Med., 138: 418 (1971).

33. This work was presented in condensed form to the European Society of Pediatric Research, Rotterdam, June 1976. (Abstract: Pediat. Res.. 10: 888 (1976).)

34. We wish to thank Dr. H. Krimer for the preparation of the Evans blue dve, 
and Ms. Monika Gïntner and Ms. Clatudia Wohlfarth for the faultless technical assistance.

35. This work was supported by Deutsche Forschungsgemeinschaft (SFB 147).

36. Requests for reprints should be addressed to: O. Linderhamp. M.I)., Univer-

Copyright at 1977 International Pediatric Research Foundation. Inc sititshinderklinik, Lindwurmstr. 4, I)-8 Munich 2 (Federal Republic of Gicmany)

37. Received for publication November. 15. 1976.

38. Accented for publication December 21, 1976 .

Printed in U.S.A.

Pediat. Res. 11: 889-893 (1973)

Adrenaline

asphyxia

catecholamines fetus

heart rate

noradrenaline

\title{
Catecholamine Release in the Newborn Infant at Birth
}

\author{
HUGO LAGIERRANTZ1331 ANI) PETER BISTOLETTI \\ Department of Physiology, Karolinska Institute, Stockholm, and Departments of Pediatrics and Obstetrics and \\ Gynecology, Karolinska Institute, Huddinge Hospial. Huddinge, Swe'den
}

\begin{abstract}
Summary
Catecholamines were determined by a fluorimetric technigue in umbilical blood which was collected from newborn infants immediately after birth. The mean catecholamine concentration was $62.1 \mathrm{nmol} /$ liter in the umbilical artery and $29.3 \mathrm{nmol} / \mathrm{liter}$ in the umbilical vein of newborn full term infants delivered uneventfully. This value is considerably higher than in resting adults. Similar levels of catecholamines were seen after elective cesarean sections, whereas considerably higher levels were found after breech deliveries. In the full term asphyxiated infants about a 4-fold increase of the catecholamine concentration was found in both the umbilical arterial and venous blood. The amine concentration level correlated inversely to the pll below 7.25 ( ${ }^{16} \mathrm{log}$ catecholamine concentration versus $\left.\mathrm{pH}, r=\mathbf{- 0 . 7 1}\right)$. Preterm infants had, in general, lower amine levels than full term infants both after uneventful deliveries and after intrauterine asphyxia. The catecholamine levels were considerably increased in the newborn infants who showed some kind of abnormal fetal heart rate variation during the last hour before birth; in particular baseline changes were associated with high levels whereas only a moderate increase was seen after loss of beat-tobeat variation.
\end{abstract}

\section{Speculation}

The high catecholamine concentrations in umbilical blood, seen even after uneventful deliveries, indicate that the sympathoadrenal system might have a functional role in the fetus at delivery. The enormous levels at asphyxia might be of importance to sustain the circulatory homeostasis.

The sympathoadrenal system is certainly of great importance for the regulation of the fetal heart rate during delivery. Determination of catecholamines (preferably in scalp blood samples) can be a valuable tool in the study of cardiotocography.

Studies on fetal sheep have demonstrated that adrenergic cardiovascular control is well developed at term $(11,19,23)$. Probably there are fewer noradrenaline stores in the sympathetic nerve terminals of the fetus compared with the adult (11); on the other hand, there are increased catecholamine stores in the adrenal medulla per $\mathrm{kg}$ body weight (7) and possibly also in the paraganglia. The isolated fetal heart is more sensitive to catecholamines than the adult heart; this supersensitivity has been compared to that of the denervated organ (11). These findings indicate that the circulating catecholamines may play a greater role in the fetus than in the adult (11). Hypoxia induces a large increase of the catecholamine secretion from the adrenal medulla (15). Even during moderate hypoxia (fetal arterial pO.

$18 \mathrm{~mm} \mathrm{Hg}$ during $1 \mathrm{hr}$ ) more than 10-fold increase of the catecholamine concentration in plasma was found. Catecholamines administrated to the fetal sheep in similar concentrations to these released during mild hypoxia were found to cause large cardiovascular effects (21).

On the basis of the findings in fetal sheep this study was performed to investigate the sympathoadrenal activity in the human newborn. Catecholamines were determined in umbilical blood and the levels were correlated with signs of fetal hypoxia such as Apgar score and blood gases. Particular interest was paid to the problem of whether there was any relation between the catecholamine level and abnormal fetal heart rate patterns before birth.

\section{MATERIALS ANI) METHODS}

Plasma catecholamines were determined in a number of newborn infants delivered at Huddinge Hospital. The infants were classified in various groups according to clinical conditions (group $A$ ) and according to fetal heart rate patterns (group B).

\section{GROUP A: CLINICAI CONDITIONS CLASSIFICATION}

Group i: Full Term Infants Delivered Uneventfully. All of these cases were delivered vaginally in vertex position; their fetal heart rate patterns were found to be essentially normal (see below) and their Apgar scores were above 7 at 1 min. The infants in this group had a gestational age of 37-4.3 wecks and were appropriate in weight for gestational age.

Group ii: Preterm Infents. Delivered Uneventfully. These infants fulfilled the same conditions as above, except that the gestational age was less than 37 weeks.

Group iii: Infants Delivered by Elective Cesarean Section. Maternal indications such as small pelvis, long sterility, and the 